Katarzyna Dormus

DOI: $10.14746 /$ BHW.2015.33.2

Wydziat Pedagogiczny

Uniwersytet Pedagogiczny w Krakowie

\title{
Wątek kształcenia dziewcząt $w$ reformach szkolnych od czasów Komisji Edukacji Narodowej do II wojny światowej
}

\begin{abstract}
Girls' education as an element of school reforms from the Commission of National Education up to WWII

At the end of the 18th century and during the partitions, the education of young females constituted a separate educational track. At elementary level, young females had access to regular schools. At secondary level, private and monastic schools dominated. The government's first interference with the education of young females was, perhaps, the attempt by the Commission of National Education to establish the permanent supervision of certain female schools (under legislation from 1775).

The laws regarding education in each partition were not commensurate with the growing educational aspirations of women and the general socio-economic conditions. The Russian Partition was characterised by the dual existence of Polish private schools and governmental schools focused on the Russification of young Polish females. In Galicia, the most controversial issue was the creation of female secondary schools, the completion of which would enable a young woman to pursue university studies. Only during the Second Polish Republic did female education achieve equality before the law.
\end{abstract}

Keywords: girls' education, educational reforms, schools, Poland

Na przestrzeni prawie stu pięćdziesięciu lat od chwili powstania Komisji Edukacji Narodowej po wybuch II wojny światowej reform szkolnych polskich lub dotyczących polskiego społeczeństwa było niemało, podejmowanych i przeprowadzanych w bardzo różnych warunkach polityczno-społecznych. W decyzjach dotyczących funkcjonowania oświaty poruszana była też kwestia kształcenia dziewcząt. Aż do powstania niepodległego państwa polskiego edukacja dziewcząt i edukacja chłopców stanowiły dwa odrębne tory edukacyjne, które na poziomie elementarnym splatały się ze sobą, rozchodząc się na 
szczeblu szkolnictwa ponadelementarnego i średniego, by złączyć się znów na poziomie szkolnictwa wyższego. Na poziomie szkolnictwa elementarnego przeprowadzane reformy dotyczyły tego szkolnictwa w całości, a sprawy kształcenia dziewczynek były w nich uwzględnianie jako jeden z elementów. Na szczeblu ponadelementarnym i średnim wiele z nich odnosiło się już wyłącznie do szkolnictwa żeńskiego i one też wywoływały najwięcej dyskusji. Na decyzje w tej sferze wpływały bowiem poza czynnikami politycznymi, ekonomicznymi i organizacyjnymi, kwestie światopoglądowe oraz tradycja określające stosunek społeczeństwa i władz do tzw. kwestii kobiecej oraz wymogi realnego życia w zmieniających się dynamicznie warunkach XIX i XX stulecia, wymuszające np. podejmowanie przez kobiety pracy zarobkowej wymagającej wyższych kwalifikacji. Natomiast wejście kobiet na uniwersytety dokonało się nie przez reformę, lecz dzięki zgodzie na wkroczenie kobiet w tradycyjnie funkcjonujące struktury, nie pociągając za sobą zmiany sposobu ich funkcjonowania.

Na poziomie szkolnictwa początkowego decyzje dotyczące kształcenia dziewczynek podejmowane były w ramach poszczególnych reform dotyczących szkół parafialnych czy ludowych. W XVIII w. było już utrwaloną tradycją, że do szkół parafialnych uczęszczały one wspólnie z chłopcami i ten stan rzeczy nie uległ zmianie. Postanowienia dotyczące dziewcząt odnosiły się zatem do pewnych odrębności programowych, zatrudniania nauczycielek zajmujących się edukacją dziewcząt czy rozważań na temat granic wiekowych i warunków funkcjonowania koedukacji. Postanowienia Komisji Edukacji Narodowej odnoszące się do kształcenia dziewcząt na poziomie elementarnym również stanowiły w dużym stopniu akceptację stanu zastanego ${ }^{1}$. W Ustawach Komisji Edukacji Narodowej z 1783 r. - zasadniczym dokumencie ujmującym całość przepisów reformatorskich - w rozdziale o szkołach parafialnych nie ma mowy osobno o dziewczynkach, a tym bardziej o odrębnych szkołach żeńskich czy odmiennych programach nauczania ${ }^{2}$. Nieco więcej informacji na ten temat można znaleźć w Powinnościach nauczyciela Grzegorza Piramowicza, które można uznać za wykładnię przepisów Komisji. Piramowicz używa terminu „dzieci”, nie dzieląc ich wedle płci. Jest tylko jeden fragment, w którym wymienia osobno chłopców i dziewczynki - początek rozdziału „O celu, obowiązkach nauczyciela". Jest to równocześnie fragment, w którym ogólnie kreśli cel nauczania i wychowania w szkole parafialnej ${ }^{3}$.

W Powinnościach znajduje się także dodatek „O mistrzyniach płci niewieściej”, o tyle ważny, że po raz pierwszy jest w nim mowa o kobietach nauczycielkach w szkole parafialnej, a także dlatego, że zawiera sporo informacji na temat wychowania i kształcenia dziewcząt. Według Piramowicza celem wychowanie dziewczynki było przygotowanie jej do przykładnego wypełniania ról matki, żony, gospodyni, ,sługi” i ,robotnicy”. Program szkółek parafialnych miał być zasadniczo jednakowy dla chłopców i dziewczynek w zakresie: czytania, pisania, rachunków, wychowania religijnego i moralnego.

${ }^{1}$ H. Pohoska, Sprawa oświaty ludu w dobie Komisji Edukacji Narodowej, Kraków 1925, s. 80.

2 Ustawy Komisji Edukacji Narodowej dla Stanu Akademickiego i na szkoły w krajach Rzeczypospolitej przepisane w Warszawie roku 1783, Lwów 1917, s. 116.

${ }^{3}$ G. Piramowicz, Powinności nauczyciela, oprac. T. Mizia, Warszawa 1988, s. 93. 
Zróżnicowanie następowało w zakresie przedmiotów praktycznych. Nie wszystkie nauki równie chłopiętom i panienkom sa potrzebne - stwierdzał Piramowicz. Dziewczynki powinny zdobywać zasób wiadomości i umiejętności związanych z prowadzeniem gospodarstwa domowego. Na tych więc rzeczach więcej czasu łożyć mistrzyni z uczennicami będzie - pisał Piramowicz - niżeli w szkole na czytaniu $i$ pisaniu. Przeważać zatem miały cele praktyczne ${ }^{4}$.

W czasach Księstwa Warszawskiego odwołano się do dorobku i tradycji Komisji Edukacji Narodowej. Izba Edukacyjna kierująca polityką oświatową dużo uwagi poświęciła szkolnictwu elementarnemu, starając się torować drogę zasadzie powszechności. Urządzenie szkół miejskich i wiejskich elementarnych zatwierdzone w dniu 12 I 1808 r. oraz wydany dnia 16 X 1808 r. Regulament szkót miejskich i wiejskich elementarnych, przeniknięte duchem oświecenia i zaleceniami Pestalozziego, stanowiły podstawą prawną dla całego systemu oświaty ludowej. Zalecano, aby w każdej wsi i mieście istniała szkoła. Ustanowiono obowiązek szkolny (bez przymusu szkolnego), nad realizacją którego miały czuwać dozory szkolne. Były one zobowiązane do spisania wszystkie dzieci obu płci - na wsiach od 8 lat, a w miastach od 7 roku życia. Dziecko miało uczęszczać do szkoły do 11-12 roku życia, póki nie nabędzie wiadomości potrzebnych. Program nauczania dla dziewcząt prócz programu ogólnego (czytanie, pisanie, rachunki, nauka moralna i religia, nauka o zdrowiu i wiadomości rolnicze, geometria, nauka o miarach i wagach, prawo) przewidywał naukę robót kobiecych i gospodarskich ${ }^{5}$.

Izba Edukacyjna zachęcała, aby po wsiach i miastach posyłano dziewczęta do szkót elementarnych razem z chłopcami, w szkołach miejskich umieszczała nawet nauczycielki robót kobiecych, ale warstwy wyższe nie chciały tam posytać swoich córek - pisze Jan Hulewicz ${ }^{6}$. Liczba dziewcząt w szkołach elementarnych wahała się na ogół od kilkunastu do $40 \%{ }^{7}$.

Upowszechnienie szkoły ludowej stanowiło jeden z najistotniejszych problemów szkolnych i społecznych w XIX w. - władzom państwowym zaczęło bowiem zależeć na tym, by edukacją objąć jak największą liczbę poddanych i ukształtować ich na pożytecznych i lojalnych obywateli. Stąd wypływały starania o wprowadzanie obowiązku szkolnego popartego z czasem przymusem szkolnym oraz zgoda na koedukację na poziomie szkoły ludowej. Zarówno wprowadzenie obowiązku szkolnego, jak i koedukacja były korzystne dla dziewczynek. Obowiązek szkolny obligował rodziców lub opiekunów do posyłania dziewcząt do szkół, co było o tyle ważne, że o ich wykształcenie troszczono się zazwyczaj w drugiej kolejności. Istnienie szkół mieszanych pozwalało na realizację tego obowiązku, w Europie bowiem na ogół nie istniały warunki ekonomiczne i organizacyjne pozwalające na równolegle funkcjonowanie szkół ludowych męskich i żeńskich

\footnotetext{
4 Ibidem, s. 159-160.

5 A. Winiarz, Szkolnictwo Księstwa Warszawskiego i Królestwa Polskiego (1807-1831), Lublin 2002, s. 98-102; S. Kot, Historia wychowania, t. II, Warszawa 1996, s. 242; K. Poznański, Osiagnięcia polskich reform szkolnych w XIX wieku, „Kwartalnik Pedagogiczny” 1995 nr 3, s. 149.

${ }^{6}$ S. Kot, op. cit, t. II, s. 246.

7 A. Winiarz, op. cit., s. 111 .
} 
w jednej wsi lub miejscowości. W okresie zaborów sytuacja dziewcząt w szkołach ludowych zależna była od ogólnej polityki oświatowej prowadzonej przez poszczególne państwa zaborcze.

Pozytywne przemiany zapoczątkowane przez Izbę Edukacyjną uległy zahamowaniu w czasach Królestwa Polskiego. Wedle Ustawy dla gimnazjów, szkół obwodowych i elementarnych czyli parafialnych w Królestwie Polskim z 1833 r. do szkół parafialnych mogły być przyjmowane dzieci obojga płci, które ukończyły 8 rok życia, z tym że dziewczynki nie mogły być starsze niż jedenastoletnie. Ponieważ zapisy do szkoły prowadzono corocznie, oznaczało to, że chłopcy mogli się uczyć znacznie dłużej. Liczba dziewczynek w poszczególnych szkołach była różna, ale bywały takie, w których stanowiły nawet połowę uczniów. W 29 szkołach, w których fundusze na to pozwoliły, utworzono nawet oddzielne klasy dla płci żeńskiej ${ }^{8}$.

W wyniku kolejnej ustawy szkolnej z 1851 r. nie tylko zunifikowano szkolnictwo Królestwa ze szkolnictwem rosyjskim, ale zrujnowano je m.in. znosząc obowiązek szkolny. Podjęta w 1862 r. przez Wielopolskiego reforma szkolna stanowiła próbę odbudowy szkolnictwa polskiego. Wielopolski był zwolennikiem wprowadzenia obowiązku szkolnego pod rygorem kar pieniężnych, jednak nie uzyskał na to zgody władz rosyjskich. Szkoły elementarne miały powstawać w każdej gminie i być dostępnymi dla wszystkich dzieci. Wybuch powstania styczniowego nie pozwolił na zrealizowanie założeń tej reformy.

Przegrana Rosji w wojnie krymskiej zmusiła Aleksandra II do podjęcia decyzji o przeprowadzeniu szeregu reform społecznych i gospodarczych. Najważniejszą z nich była reforma uwłaszczeniowa na wsi. W jej obliczu położono nacisk na szerokie upowszechnienie oświaty elementarnej na wsi. W dniu 30 VIII/11 IX 1864 r. car zatwierdził w Jugenheim projekty nowych ustaw i wystosował oficjalny reskrypt, w którym wytyczał nowy kurs polityki oświatowej w Królestwie Polskim. W zaborze rosyjskim kurs ten wiązał się ze wzmożoną rusyfikacją. W zakresie sytuacji dziewcząt w szkołach początkowych reformy te nie przyniosły zasadniczych zmian, a brak wprowadzenia obowiązku szkolnego zapewne bardziej niekorzystnie odbijał się na sytuacji dziewczynek aniżeli chłopców ${ }^{9}$.

Swoim dorobkiem w dziedzinie organizacji szkolnictwa od początku XIX w. wyróżniały się Prusy ${ }^{10}$, gdzie najwcześniej i najskuteczniej stworzono system powszechnego, jednolitego i obowiązkowego szkolnictwa na szczeblu elementarnym. Szkoła ludowa miała spełniać ważne zadania polityczne, dlatego wszystkim dzieciom, bez różnicy płci, nakazano uczęszczanie do szkół. Ustawa z 1825 r. wprowadzała obowiązek szkolny na

\footnotetext{
${ }^{8}$ K. Poznański, Oświata i szkolnictwo w Królestwie Polskim 1831-1869. Lata zmagań i nadziei, t. 1: Przebudowa systemu szkolnictwa $i$ wychowania $w$ Królestwie Polskim w latach 1831-1839, Warszawa 2001, s. 56, 59. Ustawa ta wzorowana była na rosyjskiej ustawie z 1828 r., bardzo wyraźnie podkreślała stanowy charakter edukacji.

${ }^{9}$ K. Poznański, Reforma szkolna w Królestwie Polskim w 1862 roku, Wrocław 1968, s. 283; S. Kot, op. cit., t. II, s. 297.

10 J. Miąso, Reformy oświatowe w Prusach, Austrii i Rosji i ich wplyw na szkolnictwo na ziemiach polskich $w$ drugiej połowie XIX wieku, „Kwartalnik Pedagogiczny” 1995, nr 3, s. 124; K. Poznański, Osiagnięcia polskich reform..., s. 141.
} 
terenie Wielkopolski i Pomorza dla dzieci w wieku od 6 do 14 lat, egzekwowany pod sankcją surowych kar. Ustawy szkolne z 1872 r. stworzyły podstawy nowoczesnego szkolnictwa elementarnego. Program szkół został rozszerzony m.in. o przedmioty realne prowadzone teraz w szerszym wymiarze. Dla dziewcząt obowiązkowymi były roboty praktyczne, a potem także przedmioty rolnicze. Tak zmodernizowana szkoła przetrwała do 1914 r., a reformy przyniosły wymierny efekt w postaci likwidacji analfabetyzmu. Dla Polaków jednak funkcjonowanie szkoły silnie kontrolowanej przez państwo oznaczało germanizację $^{11}$. Na ziemie przejęte w wyniku rozbiorów Austria natychmiast rozciągnęła własne ustawodawstwo szkolne. Zgodnie z przepisami opracowanymi przez Jana Ignacego Felbigera w każdej miejscowości i wsi miała się mieścić szkoła ludowa zwana trywialną, w której dzieci miały się uczyć czytania, pisania i rachunków oraz wiadomości praktycznych, a dla dziewcząt przewidywano jeszcze roboty ręczne. Szkółki mogły być mieszane, jednak chłopcy i dziewczynki mieli siedzieć w osobnych ławkach. Wszystkie działające szkoły były niemieckie i miały służyć germanizacji ${ }^{12}$. Sytuacji dziewcząt w tych szkołach nie zmieniła też ustawa z 1805 r. zwana polityczną, która w całościowy sposób regulowała sprawę szkolnictwa elementarnego i obowiązywała do czasów uzyskania przez Galicję autonomii ${ }^{13}$.

Kolejne reformy, liberalne już w swoim duchu, przyniosła 2 poł. lat 60. XIX w., co związane było z przemianami wewnętrznymi w monarchii habsburskiej. W dniu 14 maja 1869 r. wydano ogólnopaństwową ustawę o szkołach ludowych, zapoczątkowująca budowę nowoczesnej szkoły elementarnej, ogólnokształcącej, publicznej, jednolitej i obowiązkowej, która z biegiem czasu stała się jednym z ważniejszych czynników postępu cywilizacyjnego oraz wzrostu samowiedzy narodów i narodowości znajdujacych się pod panowaniem Habsburgów ${ }^{14}$.

Ustawa zakładała istnienie 5-letniej szkoły ludowej i na jej podbudowie 3-letniej szkoły wydziałowej. Nadzór szkolny miały sprawować rady szkolne. Wprowadzała obowiązek szkolny dla dzieci w wieku od 6 do 14 lat. Stworzono jednolite ogólnokształcące programy nauczania, nie uwypuklając ich utylitarnego ukierunkowania. Dziewczęta jednak miały obowiązkowo uczyć się robót kobiecych i gospodarstwa domowego ${ }^{15}$.

$\mathrm{Na}$ bazie tej ustawy władze krajowe Galicji w dniu 2 maja 1873 r. wydały Ustawe o zakładaniu i utrzymywaniu publicznych szkół ludowych i obowiązku posytania do nich dzieci. W stosunku do ustawy ogólnopaństwowej ograniczono obowiązek szkolny, obejmując nim dzieci od 6 do 12 roku życia. Po ukończeniu szkoły ludowej dzieci miały obowiązek dokształcania się w szkołach niedzielnych. W sprawie organizacji szkół zale-

11 J. Miąso, op. cit., s. 124.

12 E. Suchan, Historyczny zarys organizacji szkolnictwa elementarnego w Polsce od Komisji Edukacji Narodowej po dobę obecną, Brześć nad Bugiem 1938, s.64; S. Kot, op. cit., t. II, s.218; K. Poznański, Osiagnięcia polskich reform..., s. 142.

13 S. Kot, op. cit.., t. II, s. 220-221, 268.

14 J. Miąso, op. cit., s. 130-131. Ustawa ta utrzymała się bardzo długo, z pewnymi zmianami zastąpiła ją dopiero nowa ustawa w $1962 \mathrm{r}$.

15 Ustawy i rozporządzenia w zakresie szkót ludowych, zebrał i ułożył K. Pierożyński, Lwów 1904, s.430; R. Dutkowa, Polityka szkolna w Galicji między autonomia a centralizmem (1861-1875), Kraków 1995, s. 133. 
cano: Gdzie tylko fundusze miejscowe wystarczaja, mają dziewczęta oddzielnie pobierać naukę lub urzązić się osobne szkoty żeńskie. Podziat taki nastąić musi w szkołach, w których więcej niż sześciu nauczycieli jest zatrudnionych. Niemniej podzielona ma być szkoła na dwie osobne, dla chłopców i dziewcząt, jeżeli napływ uczniów i uczennic do niej w pięciu ostatnich po sobie następujacych latach byt tak wielki, że musiano z większej połowy klas tworzyć po dwa wspótrzędne oddziały ${ }^{16}$.

Kolejne ustalenia co do organizacji szkół ludowych i programu nauczania wniosły Plany nauki dla szkół ludowych pospolitych z 1893 r. o zdecydowanie bardziej konserwatywnym charakterze. Zgodnie z nimi nauka w szkole ludowej powinna mieć charakter głównie praktyczny. U dziewczynek nauka ta ma być zastosowana do potrzeb gospodarstwa domowego, a u chlopców do potrzeb gospodarstwa wiejskiego i domowego przemystu ${ }^{17}$ - stwierdzano. Jak podkreślano nauka robót ręcznych kobiecych ma doniosłe znaczenie pedagogiczne $w$ szkole wiejskiej $i$ małomiasteczkowej $[\ldots]^{18}$ i ma odbywać się wtedy, gdy chłopcy mają gimnastykę. Cztery niższe klasy szkoły ludowej mogły być mieszane $^{19}$, lecz klasa $V$ musi być co do ptci rozdzielona ${ }^{20}$. Te same stwierdzenia powtarzały się w planach z $1911^{21}$.

Władze krajowe zajęły się też szkołami wydziałowymi, które większe znaczenie miały dla dziewcząt, niemających możliwości uczęszczania do szkół średnich. Ustawa krajowa z dnia 2 lutego 1885 r. dotycząca publicznych szkół ludowych nakazywała tworzyć osobne szkoły wydziałowe męskie i żeńskie z 4-letnim kursem nauki. Ponadto stwierdzała, że dla dziewcząt nauka stosować się będzie do właściwych tej płci potrzeb i usposobień i przyszłego jej stanowiska $w$ rodzinie, uwzględniając przede wszystkim potrzeby rozleglejszego wyksztatcenia ogólnego, a nie spuszczając z oka praktycznych także potrzeb. Dla dziewcząt miały być zatem prowadzone zajęcia z zakresu gospodarstwa domowego i robót kobiecych, zaś higiena będzie wykładana w sposób ile możności wyczerpujacy ${ }^{22}$.

Ustawy krajowe z lat 1885 i 1895 przekształciły niektóre szkoły wydziałowe w zakłady najpierw 4-klasowe na podbudowie 5-klasowej szkoły pospolitej, a potem w szkoły 6-letnie. Artykuł 14 Ustawy o zakładaniu i urządzaniu publicznych szkół ludowych i obowiazku posytania do nich dzieci z dnia 23 maja 1895 r. tworzył typ wyższej szkoły wydziałowej, niepołączonej ze szkołą pospolitą. Tego typu szkoły miały powstawać je-

\footnotetext{
${ }^{16}$ Dziennik ustaw i rozporządzeń krajowych dla Królestwa Galicji i Lodomerii wraz z Wielkim Księstwem Krakowskim, rok 1873, cz. XXVIII, art. 8, s. 182, 190.

17 Plany nauki dla szkót ludowych pospolitych wraz z instrukcją, Lwów 1893, Instrukcja, s. 42.

18 Ibidem, s. 107.

19 Ibidem, s. 4.

${ }^{20}$ Ibidem, Uwagi dotyczące klasy V, s.1.

${ }^{21}$ Plany naukowe dla szkót ludowych pospolitych pięcio- $i$ sześsioklasowych męskich, żeńskich i mieszanych wraz z instrukcja, Lwów 1911.

${ }^{22}$ Dziennik ustaw i rozporządzeń..., Rok 1885, cz. VIII, s. 88-89. Na mocy ustawy powołano sześć szkół wydziałowych żeńskich: we Lwowie, Krakowie, Tarnowie, Rzeszowie, Stanisławowie, Tarnopolu, potem powstawały kolejne.
} 
dynie w większych miastach ${ }^{23}$. Zwolennikiem ich tworzenia był wiceprezydent Rady Szkolnej Krajowej Michał Bobrzyński, który uważał, że powinny one zaspokoić aspiracje edukacyjne dziewcząt domagających się coraz wyraźniej zakładania żeńskich szkół średnich. Zdumiewa różnorodna funkcja szkót wydziałowych - stwierdza Renata Dutkowa - traktowano je bowiem jako wyższe szkoty elementarne żeńskie, quasi średnie tzw. „,wydziałowe szkoły licealne”, a ponadto - jako szkoły zawodowe. Każda ze specjalizacji uzależniona była jednak od liczby klas $i$ specyficznego programu nauczania ${ }^{24}$. Zreformowana w taki sposób szkoła nie mogła jednak zadowolić zwolenników prądów emancypacyjnych, ograniczony bowiem program nauczania w zakresie języków klasycznych i przedmiotów przyrodniczo-matematycznych stanowił skuteczną zaporę dla dążeń kobiet do kształcenia się na wyższych szczeblach ${ }^{25}$. Tak ukształtowany system szkolny przetrwał w Galicji do końca zaborów.

Na szczeblu szkolnictwa elementarnego w okresie od czasów Komisji Edukacji Narodowej po wybuch I wojny światowej sytuacja dziewczynek kształtowała się podobnie. Wszędzie dopuszczano je do szkół elementarnych na równi z chłopcami, jednak podejmowano też starania, by w miarę możliwości wprowadzać rozdział płci. Istniały też odmienności programowe wprowadzone ze względu na przyszłe role i zadania kobiet, a ideał wychowawczy dotyczący dziewczynek był modyfikowany właśnie pod kątem tych ról.

Próba opisu kształcenia dziewcząt na stopniu ponadelementarnym lub średnim przysparza znacznie więcej trudności. Wynika to z niejednolitości systemu kształcenia dziewcząt, różnorodności szkół dla nich przeznaczonych oraz trudności ze sprecyzowaniem, czy daną szkołę można uznać za szkolę ponadelementarną, czy już średnią, a może jednak przypisać ją do poziomu szkół elementarnych. Najlepszy, choć nie jedyny przykład, stanowi wspomniana już wyższa szkoła wydziałowa w Galicji, która organizacyjnie przynależała do stopnia elementarnego, choć traktowana bywała jako szkoła quasi-średnia.

Zasługa włączenia po raz pierwszy kwestii szkolnictwa żeńskiego do szerokiego programu reform przypada Komisji Edukacji Narodowej, a było to przedsięwzięcie nowatorskie również w skali Europy. Wynikało z głębokiego przekonania, że wychowanie dziewcząt jest jednym z filarów odrodzenia patriotycznego i obywatelskiego. Jednocześnie było sprzeczne z zakorzenionym głęboko w społeczeństwie przekonaniem, że dziewczęta powinny być wychowywane w domach rodzinnych pod okiem matki ${ }^{26}$. Przekonanie to zresztą będzie ważyć bardzo silnie przez całą 1 poł. XIX w. na decyzjach dotyczących szkolnictwa żeńskiego.

\footnotetext{
${ }^{23}$ Szkoły takie powstały w Krakowie, Lwowie i Rzeszowie.

${ }^{24}$ R. Dutkowa, Żeńskie gimnazja Krakowa w procesie emancypacji kobiet (1896-1918), Kraków 1995, S. 12 .

25 Ustawy i rozporządzenia..., s. 11 (art. 7), 111, 114; Dziennik ustaw i rozporządzeń dla Królestwa Galicji i Lodomerii wraz z Wielkim Księstwem Krakowskim. Rocznik 1895, Lwów, cz. XII, s.183; R. Dutkowa, Żeńskie gimnazja..., s. 8.

${ }^{26}$ K. Bartnicka, Pensja żeńska jako substytut wychowania domowego, w: Nauczanie domowe dzieci polskich od XVIII do XX wieku, red. K. Jakubiak i A. Winiarz, 2004, s. 168.
} 
Komisja Edukacji Narodowej już na początku swej działalności podjęła starania o uporządkowanie sytuacji panującej na pensjach, do których uczęszczały dziewczynki z warstw zamożniejszych. Tą zaniedbaną dotąd dziedziną edukacji zajął się książę Adam Kazimierz Czartoryski. W listopadzie 1774 r. powierzono mu nadzór nad szkolnictwem prywatnym męskim i żeńskim, polecając opracowanie odpowiednich przepisów. W dniu 24 III 1775 r. zostały one zatwierdzone. Zawarto w nich osobne przepisy dla szkół żeńskich, które można uznać za pierwsze przepisy państwowe tych szkół dotyczące.

Dokument odnosił się do wszystkich szkół prywatnych w całej Rzeczypospolitej z wyłączeniem szkół klasztornych ${ }^{27}$. Za pensje uznano zakłady internatowe, działające za zezwoleniem Komisji, w których mogło przebywać od 10 do12 uczniów lub uczennic w wieku od 6 do16 lat. Koedukacja była zabroniona za wyjątkiem pierwszego roku $1775 / 76^{28}$. Program nauki był identyczny dla dziewcząt i chłopców z wyjątkiem łaciny, zamiast której dziewczęta miały geografię. Ten brak łaciny dla dziewcząt stanowił odtąd regułę stosowaną w ciągu całego wieku XIX w., bardzo brzemienną w skutki, bo uniemożliwiającą dziewczętom w dalszej przyszłości wstęp na studia wyższe. Dużą wagę przywiązywano do wychowania obywatelskiego i patriotycznego uczennic, które - jak podkreślano - będą w przyszłości oddziaływały na mężczyzn ze swojego najbliższego otoczenia: braci, mężów, synów. Po raz pierwszy jasno sformułowano zadania kobiety -Polki. W przypadku dziewcząt akcent został zresztą mocniej położony na wychowanie społeczne i narodowe, aniżeli na kształcenie umysłowe ${ }^{29}$.

W Ustawach z 1783 r. nie zamieszczono osobnego rozdziału dotyczącego szkolnictwa żeńskiego. Jedynie w rozdziale „Rektor wydziałowy, prorektor” jest wspomniane, że rektorowi podlegają wszystkie szkoły wydziału, w tym też pensje żeńskie, które mogą być otwierane jedynie za zgodą Komisji i po sprawdzeniu kompetencji oraz obyczajów zakładającego placówkę, i które rektor ma obowiązek wizytować.

Komisja Edukacji Narodowej nie zdołała przeprowadzić całkowitej reformy szkolnictwa żeńskiego. Nie udało się objąć pensji pełnym dozorem państwowej władzy oświatowej. Poziom ich był niski, było ich niewiele i mało liczne (nawet po 3-4 uczennice) ${ }^{30}$.

Do sprawy uporządkowania sytuacji w szkolnictwie żeńskim powrócono na szerszą skalę w czasach Księstwa Warszawskiego. Izba Edukacyjna podjęła szereg poczynań mających na celu uregulowanie funkcjonowania pensji oraz szkół prywatnych. Przesiąknięta głęboko ideałami Komisji Edukacji Narodowej i nawiązująca do jej stanowiska, podzielała ambiwalentny stosunek Komisji do pensji, uznając dom rodzinny za najwła-

27 M. Miterzanka, Działalność pedagogiczna Adama księcia Czartoryskiego generała ziem podolskich, Prace monograficzne z dziejów wychowania i szkolnictwa w Polsce, s. I, nr 8, Warszawa 1931, s. 197-199.

28 Przepisy od Komisji Edukacji narodowej pensjo mistrzom i pensjo mistrzyniom dane, w: Ustawodawstwo szkolne za czasów Komisji Edukacji Narodowej. Rozporzadzenia, ustawy pedagogiczne i organizacyjne (1773-1793), zebrał J. Lewicki, Biblioteka Polskich Pisarzy Pedagogicznych nr 2, Kraków 1925, s. 69.

${ }^{29}$ Ibidem, s. 69-75; J. Lewicki, Komisja Edukacji Narodowej w świetle ustawodawstwa szkolnego. Szkic historyczny, Warszawa 1923, s. 27-28; J. Ender, Sprawa kształcenia kobiet $w$ dobie Komisji Edukacyjnej, „Przegląd Historyczno-Oświatowy” 1972, nr 3, s. 471-472, 474.

${ }^{30}$ Ustawy Komisji Edukacji Narodowej..., s. 68-70; J. Ender, op. cit., s. 476-477, 481; K. Bartnicka, op. cit., s. 169. 
ściwsze miejsce wychowywania dziewcząt i w konsekwencji podkreślała, że wychowanie prowadzone na pensjach ma przypominać wychowanie domowe, zaś funkcje wychowawcze mają górować nad kształcącymi.

W Planie Edukacji Publicznej z dnia 1 XII 1807 r. uregulowano odrębnymi przepisami nadzór nad zakładaniem i funkcjonowaniem pensji. W październiku 1808 r. powołano pierwsze dozory departamentowe pensji i szkół kobiecych, a najsilniejszemu z nich warszawskiemu - Izba Edukacyjna zleciła przeprowadzenie wizytacji i przygotowanie wniosków. Opierając się w znacznej mierze na nich, eforki (z dużym udziałem Izy Czartoryskiej) opracowały „Regulament pensji i szkół płci żeńskiej”, który został zatwierdzony w dniu 9 III 1810 r. Uznaje się go za pierwszy polski akt normatywny regulujący w całościowy sposób sprawy edukacji dziewcząt. „Regulament” wprowadzał ścisły podział placówek żeńskich na pensje i szkoły, określał ich organizację, program nauczania, cele kształcenia i wychowania. Zamieszczono w nim też przepisy dotyczące zakładania pensji, kwalifikacji nauczycieli, nadzoru, standardów dotyczące mieszkania i utrzymania na pensji. Bardzo wyraźnie przebija w nim tradycyjne przekonanie, że najwłaściwszym miejscem dla kobiet jest dom, a najwłaściwszym wychowaniem dla nich jest wychowanie domowe. Pensja stanowić miała niejako dom zastępczy, dlatego też zalecano roztoczyć nad dziewczętami bardzo ścisłą opiekę, zaś pensję traktować jako placówkę zamkniętą.

Pensje z pełnym kursem miały być szkołami 4-letnimi i 4-klasowymi. Mogło na nich przebywać nie więcej niż 15 dziewcząt, w wieku do 14 lat. Za zgodą dozoru naukę na pensjach mogły pobierać jeszcze uczennice dochodzące w liczbie nie większej niż 6 . Koedukacja była wykluczona. Program nauczania był dość obszerny, obejmował naukę języka polskiego, francuskiego i niemieckiego, arytmetykę i buchalterię, historię, geografię, botanikę. Poszerzono go o różne informacje praktyczne, roboty ręczne, wiadomości o wychowaniu dzieci, elementy wychowania fizycznego i higienę. Uczennice miały możliwość pielęgnowania „talentów”, kształcąc się w rysunkach, muzyce i tańcu. Nacisk położony był jednak na wychowanie oparte na religii i silnie przesiąknięte duchem patriotycznym. Na tym samym programie miała opierać się nauka w szkołach żeńskich.

W 1814 r. w Księstwie Warszawskim było 96 szkół i pensji żeńskich, w których uczyło się około 1050 uczennic. Poziom pensji był jednak niski, a one same nie stosowały się do zasad zawartych w „Regulamencie”. Obok nich istniały stosunkowo nieliczne szkółki zakonne ${ }^{31}$.

W pierwszych latach istnienia Królestwa Polskiego kontynuowano politykę Izby Edukacyjnej. „Urządzenie pensji i szkół dla młodzieży płci żeńskiej” z 1821 r. w dużej mierze powtarzało „Regulament”. W 1823 r. powołano nowy wielostopniowy Dozór Pensji i Szkół Wyższych Płci Żeńskiej kierowany przez ministra Stanisława Grabowskiego, m.in. przeprowadzający wizytacje. W ich efekcie w 1824 r. wydano nieco zmodyfikowane przepisy, w których precyzyjne definiowano pojęcie ,pensji” i pojęcie „,szkoły”

31 A. Winiarz, op. cit., s. 318-321; J. Hulewicz, Sprawa wyższego wykształcenia kobiet w Polsce w wieku XIX, Kraków 1939, s.12. K. Bartnicka, op. cit., s. 171-175; K. Poznański, Osiagnięcia polskich reform..., s. 155-156. 
oraz podawano kryteria służące do określania niższego i wyższego stopnia organizacyjnego. W 1825 r. wydano instrukcję określającą wymogi kwalifikacyjne dla ochmistrzyń, guwernantek, nauczycieli i metrów, a pod koniec 1826 r. „Szczegółową instrukcję względem sposobu dawania nauk na pensjach i szkłach wyższych płci żeńskiej”. Wszystkie te działania miały na celu podniesienie poziomu nauczania w szkolnictwie żeńskim. Liczba pensji w całym kraju powoli rosła. W latach 20. XIX w. było ich około $65^{32}$.

Dużym problemem był brak kadry nauczającej, szczególnie brakowało dobrze przygotowanych nauczycielek-Polek. Mając to na względzie, w 1825 r. otwarto Szkołę Guwernantek, przemianowaną pod koniec 1826 r. na Instytut Rządowy Wychowania Płci Żeńskiej. Był to najwyższy wówczas żeński zakład naukowy, do którego przyjmowano dziewczęta w wieku powyżej 14 lat po ukończeniu przez nie pensji lub szkoły trzyklasowej. Była to też pierwsza państwowa szkoła żeńska na ziemiach polskich. Przeznaczona była raczej dla niezamożnych panien, które chciały wykonywać w przyszłości zawód nauczycielski, choć mogły uczęszczać i takie, które tylko chciały uzupełnić swą edukację. Szkoła cieszyła się dużą popularnością m. in. ze względu na to, iż łatwo było po jej ukończeniu znaleźć zatrudnienie ${ }^{33}$.

Charakteryzując ów okres, Jan Hulewicz stwierdza: widać tu szczera chęć dźwignięcia tych szkót na wyższy poziom, ale wszystko to jest robione ogromnie nieśmiało, wszędzie wyczuć się daje chęć, by w niczym nie naruszać tradycyjnych form kształcenia i tradycyjnych pojęć o wychowaniu kobiet ${ }^{34}$.

W trudnym okresie międzypowstaniowym podjęto nowe postanowienia dotyczące funkcjonowania szkolnictwa w Królestwie Polskim. Od kwietnia 1840 r. do stycznia 1841 r. car podpisał szereg ustaw i rozporządzeń, które miały tworzyć nowe podstawy systemu szkolnego, a celem ich było upodobnienie sposobu funkcjonowania szkolnictwa w Królestwie Polskim do modelu rosyjskiego. Wiązało się to z nasilającym się kursem rusyfikacyjnym. Były to czasy, które w odniesieniu do szkolnictwa żeńskiego znamionowały dwie zasadnicze tendencje: rusyfikacja i chęć ograniczenia zakresu nauki dla kobiet. Zasada stanowości i otwarte bez obsłonek odżegnywanie się od wszelkiej głębszej myśli naukowej w wychowaniu kobiet zostały tu podniesione do wyżyn zasad naczelnych dążeń władz szkolnych ${ }^{35}$ - stwierdza Jan Hulewicz, dodając: rząd rosyjski kierowat sie w polityce szkolnej wobec kobiet tylko jedna dyrektywą: wychować wierne poddane tronu $i$ cesarstwa rosyjskiego [...]. Obłędny strach przed patriotyczna atmosfera rodziny polskiej kazat otoczyć niezmiernie drobiazgowymi i policyjnymi przepisami wychowanie do-

\footnotetext{
32 A. Winiarz, op. cit., s.322-325; K. Poznański, Osiagnięcia polskich reform ..., s. 169.

33 A. Winiarz, op. cit., s.329-335; J. Hulewicz, op. cit., s.16-19; J. Dąbrowska, Początki szkolnictwa żeńskiego - Instytut Guwernantek, w: Z dziejów polskiej kultury i oświaty od średniowiecza do początku XX wieku, red.. K. Jakubiak i T. Maliszewski, Kraków 2012; Szkoła-państwo-społeczeństwo, red. R. Grzybowski, t. I, s. $122-123,126-127$.

34 J. Hulewicz, op. cit., s. 18.

35 Ibidem, s. 53.
} 
mowe, $w$ braku zaś pensji rządowych raczej już tolerować istnienie szkót prywatnych jako zła mniejszego ${ }^{36}$.

W latach 40. XIX w. podjęto decyzję, iż program nauczania w szkołach żeńskich nie może być szerszy od programu obowiązującego w powiatowych szkołach męskich. Ponadto zredukowano w nich zakres nauczania przedmiotów przyrodniczych. W $1840 \mathrm{r}$. Instytut Wychowania Płci Żeńskiej przemianowano na Instytut Wychowania Panien. Miał on być szkolą 6-letnią, w której na koszt rządu uczyć się tu miały córki oficerów oraz urzędników państwowych oraz pewna liczba dziewcząt przygotowujących się do zawodu guwernantki. Treści nauczania bezceremonialnie naginano do głównego założenia wychowawczego, jakim było wzbudzenie czci i przywiazania do rosyjskiej monarchii - zauważa Adam Winiarz. W 1842 r. Instytut został przeniesiony do Puław, a do jego nazwy dodano przymiotnik „Aleksandryjski" ${ }^{37}$.

Istotne zmiany w zakresie żeńskiego szkolnictwa ponadelementarnego i średniego na ziemiach polskich przyniosła dopiero 2 poł. XIX w., kiedy z przyczyn społecznych i ekonomicznych problem zapewnienia kobietom wykształcenia na stopniu średnim, a potem wyższym stał się ogromnie aktualny i wymagał nowych rozwiązań. Podejście do tego problemu było bardzo różne, co wyraźnie widać na przykładzie Austrii i Rosji. W zaborze pruskim bowiem sprawa szkół średnich dla dziewcząt praktycznie nie istniała, podobnie zresztą jak kwestia dostępu na studia wyższe. Pruskie przepisy szkolne po kongresie wiedeńskim nie regulowały spraw kształcenia młodzieży żeńskiej na poziomie średnim aż niemal do wybuchu I wojny światowej. Szkolnictwo średnie pozostawało w gestii osób prywatnych i instytucji religijnych, a w okresie Kulturkampfu wiele z nich ulegało kasacji. Represje narodowe zbiegły się w państwie pruskim z bardzo konserwatywnym spojrzeniem na sprawę położenia kobiet ${ }^{38}$.

W Galicji właściwie trudno powiedzieć o działaniach reformatorskich zakrojonych na szerszą skalę. Działania władz można raczej określić jako szukanie rozwiązań połowicznych zmierzających do podnoszenia poziomu szkół, bez zmiany celu ich kształcenia. Ciągle bowiem bardzo wyraźnie podkreślano odrębność cech fizycznych i psychicznych dziewcząt oraz odrębność czekających je w przyszłości zadań społecznych. Ta postawa władz była niezwykle trwała, choć zdawano sobie coraz wyraźniej sprawę, że rozwiązania te nie zaspokajają rzeczywistych potrzeb kobiet.

Żadna z istniejących szkół nie odpowiadała organizacyjnie ani programowo gimnazjom męskim - szkołom średnim przygotowującym do studiów uniwersyteckich. Wszystkie, poza wyższymi szkołami wydziałowymi o dyskusyjnym statusie i seminariami nauczycielskimi, były szkołami prywatnymi. Seminaria dawały wykształcenie zawodowe na szczeblu średnim. Stanowiły niezwykle udany twór, który powstał jako jeden z ele-

36 Ibidem, s. 61.

${ }^{37}$ A. Winiarz, Kształcenie $i$ wychowanie dziewcząt w Księstwie Warszawskim i Królestwie Polskim (1807-1905), w: Kobieta i edukacja na ziemiach polskich w XIX i XX w, red. A. Żarnowska i A. Szwarc, t. II, cz. 2, Warszawa 1992, s. 14-15.

38 S. Walasek, Szkolnictwo średnie ogólnokształcace na ziemiach polskich w latach 1914-1923, „Acta Universitatis Wratislaviensis no 184, Prace Pedagogiczne CXII”, Wrocław 1996, s. 22. 
mentów reformy szkolnictwa ludowego, przeprowadzanej w skali całej monarchii na przełomie lat 60. i 70. XIX w. Seminaria były pierwszymi szkołami żeńskimi publicznymi, państwowymi, odbiegającymi od koncepcji istniejacych od dawna pensji prywatnych, świeckich i klasztornych, na ogół na niskim poziomie. Zakłady te stały się w Galicji dominujaca forma kształcenia dziewczą na poziomie ponadelementarnym - ocenia Renata Dutkowa. Szkoły te były popierane przez władze i aprobowane przez społeczeństwo, a korzystały z nich też te dziewczęta, które nie zamierzały pracować jako nauczycielki, a pragnęły jedynie zdobyć świadectwo maturalne (niedające uprawnień do studiów uniwersyteckich) $)^{39}$.

Sprawę zakładania prywatnych szkół i zakładów naukowo-wychowawczych unormowała, wielokrotnie już wspominana, ustawa państwowa z 14 V 1869 r. Szkoły prywatne mogły działać jedynie pod nadzorem władz państwowych i za zgodą Rady Szkolnej Krajowej. Niektóre z nich pod określonymi warunkami ${ }^{40}$ mogły otrzymać od Ministerstwa Wyznań i Oświecenia uprawnienia szkół państwowych. Dzięki liberalnemu charakterowi zawartych w ustawie przepisów ${ }^{41}$ nastąpił wówczas szybki rozwój średniego szkolnictwa żeńskiego. W latach 1896-1914 zaczęły powstawać pierwsze prywatne licea i gimnazja żeńskie.

Twórcą projektu liceów, 6-klasowych ogólnokształcących szkół prywatnych, był minister wyznań i oświecenia Wilhelm von Hartel, który nie był zwolennikiem ani szkół wydziałowych (jak Bobrzyński), ani gimnazjów klasycznych. Prowizoryczny statut dla liceów żeńskich został ogłoszony reskryptem Ministerstwa Wyznań i Oświecenia z dnia 11 grudnia 1900 r. Hartlowi chodziło o stworzenie szkół, których cele wychowawcze oraz program nauczania dostosowane będą do „specjalnych” potrzeb i umiejętności kobiet. Duży nacisk położono na języki nowożytne, historię i studia estetyczne. Do planu nauczania wprowadzono zajęcia z pedagogiki, psychologii, higieny. Zabrakło jednak łaciny, mało było przyrody i matematyki. Program nauczania kończył się maturą, która jednak nie dawała absolwentkom wstępu na studia wyższe w charakterze słuchaczek zwyczajnych.

Wszystkie szkoły licealne powstały w wyniku przekształcenia prywatnych zakładów naukowo-wychowawczych (pensjonatów) o charakterze szkół wydziałowych, za wyjątkiem Liceum im. Królowej Jadwigi we Lwowie przekształconego z miejskiej szkoły wydziałowej ${ }^{42}$.

39 R. Dutkowa, Żeńskie gimnazja..., s. 7. W 1871 r. Rada Szkolna Krajowa powołała do życia 9 seminariów nauczycielskich, w tym 3 żeńskie w Krakowie, Lwowie i Przemyślu.

${ }^{40}$ Warunki te dotyczyły przestrzegania regulaminu szkolnego, rozporządzeń władz szkolnych w zakresie używania zatwierdzonych oficjalnie podręczników i realizowania pełnego programu nauczania obowiązującego w szkołach państwowych.

${ }^{41}$ Otworzyć szkołę mógł każdy, kto był w stanie zabezpieczyć jej funkcjonowanie pod względem finansowym i naukowo-dydaktycznym.

42 M. Stinia, Rola społeczeństwa galicyjskiego jako organizatora średniego szkolnictwa prywatnego $w$ okresie autonomii, w: Z dziejów polskiej kultury i oświaty od średniowiecza do poczatku XX wieku, red. K. Jakubiak, t. I, s. 134; B. Czajecka, „Z domu w szeroki świat”: droga kobiet do niezależności w zaborze austriackim w latach 1890-1914, Kraków 1990, s.100-101; eadem, Szkoły klasztorne w Galicji w latach 1867-1914, „Nasza przeszłość” 1984, t. 61, s. 260; R. Dutkowa, Żeńskie gimnazja..., s. 8, 13-14. 
W roku 1906 r. Sejm krajowy na mocy ustawy z 4 kwietnia zezwolił na ujednolicenie szkół wydziałowych i liceów. Tak oto przeżyła się idea ,wyższej szkoły wydziałowej” pisze Renata Dutkowa - która w opinii społecznej została zdominowana prze licea oraz dwa inne rodzaje szkót: seminaria nauczycielskie, dajace określone wykształcenie zawodowe na szczeblu średnim i możliwość znalezienia pracy, oraz przez powstajace od schytku stulecia szkoły gimnazjalne, zaspokajajace dąienia dziewczą do uzyskania średniego wykształcenia ogólnego i otwierające drogę do studiów wyższych ${ }^{43}$.

Licea nie zaspokajały ambicji tych dziewcząt, które marzyły o maturze i studiach uniwersyteckich. Jedynym prowadzącym do tego rozwiązaniem było ujednolicenie systemu szkolnictwa ogólnokształcącego żeńskiego i męskiego. W Galicji państwo uporczywie sprzeciwiało się jednak tworzeniu rządowych szkół średnich żeńskich typu gimnazjum męskiego, choć od 1896 r. dziewczęta były dopuszczone do egzaminów dojrzałości, a od 1897 r. na uniwersytety jako studentki nadzwyczajne. Ministerstwo w okólniku z dnia 24 marca 1897 r. stwierdzało, że szkoły takie nie mogą być utrzymywane z budżetu państwa, ponieważ służyłyby tylko warstwom średnim, a to nie odpowiada potrzebom szerokich warstw ludu. U podłoża tych decyzji leżał jednak przede wszystkim strach przed nadprodukcją inteligencji powiększoną przez ewentualną konkurencję na rynku pracy ze strony kobiet ${ }^{44}$.

Jedynym rozwiązaniem było tworzenie gimnazjów prywatnych. Pierwsze takie gimnazjum powstało w Krakowie w roku 1896. Szkoły te powstawały jako odpowiedź na potrzeby społeczne, były wynikiem oddolnego działania, a nie efektem przeprowadzonej odgórnie reformy. Gimnazja żeńskie zanim w petni dostosowały się do wzorów gimnazjów męskich, przeszly wieloletnia ewolucję, prowadzaca etapami do ukształtowania się ich jako ośmioklasowych zakładów ogólnokształcacych ${ }^{45} \mathrm{Na}$ przykładzie Galicji widać - podsumowuje przemiany w sferze galicyjskiego szkolnictwa średniego Renata Dutkowa - jak wszelkie próby podniesienia poziomu (ale nie zmiany celu!) tradycyjnego ksztatcenia dziewcząt straciły na aktualności dopiero $w$ wyniku wieloletnich doświadczeñ ${ }^{46}$.

W sierpniu 1908 r. zostało wydane rozporządzenie Ministerstwa Oświaty dotyczące tworzenia 8-klasowych gimnazjów realnych i przekształconych z liceów - zreformowanych gimnazjów realnych. W tych ostatnich zamiast greki nauczano języka francuskiego oraz poszerzono program przedmiotów ścisłych i przyrodniczych. Pod względem statusu zostały zrównane z gimnazjami klasycznymi ${ }^{47}$.

Inaczej kształtowała się sytuacja żeńskiego szkolnictwa ponadelementarnego i średniego w zaborze rosyjskim. Mimo nieprzychylnych dla kobiet nastrojów wśród członków administracji szkolnej, rząd rosyjski - prawdopodobnie zdając sobie sprawę z coraz silniejszego parcia kobiet ku wyższemu wykształceniu oraz pragnąc przejąć kontrolę nad

${ }^{43}$ R. Dutkowa, Żeńskie gimnazja..., s. 15.

${ }^{44}$ Ibidem, s. 22-23.

45 Ibidem, s. 20.

46 Ibidem, s. 9.

${ }^{47}$ B. Czajecka, $Z$ domu..., s. 105-106; J. Miąso, op. cit.., s.129. Przed I wojną było 30 prywatnych gimnazjów żeńskich: 11 klasycznych i 19 realnych oraz 13 liceów. 
edukacją dziewcząt, dotąd głównie prywatną lub zakonną - zdecydował się pod koniec lat 50. XIX w. na koncesje w tej dziedzinie. Nowa polityka caratu polegała na rozbudowie rządowego szkolnictwa żeńskiego. W dniu 14 X 1856 r. wyszło rozporządzenie carskie w sprawie tworzenia w Królestwie szkół żeńskich, zbliżonych programowo do szkół gimnazjalnych. Plan rozbudowy zaczęto natychmiast realizować.

Po przeniesieniu Aleksandryjskiego Instytutu Wychowania Panien do Puław, aż do 1857 r. nie było w Warszawie średniej szkoły rządowej dla dziewcząt. Decyzją władz jesienią 1857 r. założono w Warszawie Pensję Rządową tzw. Maryjską, bardzo drogą i przeznaczoną dla córek szlachty i urzędników państwowych. Ukończenie jej dawało patent guwernantki niższego stopnia. Dwa lata później powstała Wyższa Szkoła Żeńska Rządowa, 6-letnia o dość szerokim programie nauczania, przyjmująca uczennice bez względu na ich pochodzenie społeczne oraz wyznanie. Jej ukończenie dawało patent starszej guwernantki. Równocześnie całe szkolnictwo żeńskie oddano pod opiekę cesarzowej Marii Aleksandrowny. Nadzór w jej imieniu sprawował namiestnik ${ }^{48}$. W ten sposób władze rosyjskie zapoczątkowały rozwój średniego rządowego szkolnictwa dla dziewcząt ${ }^{49}$. W działaniach tych przyświecały im jednak przede wszystkim cele rusyfikacyjne.

Reforma Wielopolskiego w 1862 r. stworzyła na moment korzystne warunki dla rozwoju prywatnych szkół żeńskich. Szkolnictwo rządowe jako rusyfikujące miało ulec redukcji. Z 9 szkół rządowych pozostały dwie: Instytut Aleksandryjsko-Maryjski (powstały z połączenia Instytutu Aleksandryjskiego i Pensji Rządowej) oraz Szkoła Wyższa Rządowa Żeńska. Zarząd nad Instytutem przejęła Komisja Rządowa Wyznań Religijnych i Oświecenia Publicznego. Program Szkoły Wyższej Rządowej Żeńskiej miał obowiązywać we wszystkich wyższych szkołach żeńskich ${ }^{50}$.

W drugiej połowie lat 60 . XX w. w Rosji nastąpił odwrót od tendencji liberalnych. Wkrótce w pełni powróciły dwie tendencje epoki paskiewiczowskiej: rusyfikacja i chęć zamknięcia wyksztatcenia kobiet w jak najciaśniejszych granicach. Wzloty doby wielopolskiego okazały się niestety krótkotrwałym epizodem - stwierdza Jan Hulewicz ${ }^{51}$. Przystąpiono do rozbudowy rządowego szkolnictwa dla dziewcząt.

Ustawa z dnia 11 września 1864 r. powoływała 6-klasowe gimnazja oraz 3-4-klasowe progimnazja żeńskie. Program rządowych gimnazjów żeńskich był zbliżony do programu męskiego gimnazjum klasycznego, ale bez łaciny i greki. Uczono natomiast tradycyjnie robót ręcznych, a jako przedmiotów nadobowiązkowych śpiewu i gimnastyki oraz odpłatnie tańca. Do szkół tych mogły wstępować dziewczęta, które ukończyły 9 lat oraz umiały czytać, pisać i rachować po polsku i rosyjsku. Ukończenie gimnazjum pozwalało na podjęcie pracy w charakterze prywatnej nauczycielki domowej, po progimnazjum natomiast można było iść do 4 lub 5 klasy gimnazjum. Celem, który przyświecał reformie

\footnotetext{
48 A. Winiarz, Kształcenie i wychowanie..., s.15-16; K. Poznański, Reforma szkolna..., s. 40-41.

49 Potem podobne szkoły powstały w Lublinie, Radomiu, Płocku, Suwałkach i Kaliszu.

${ }^{50}$ K. Poznański, Reforma szkolna ..., s. 250-252.

51 J. Hulewicz, op. cit.., s. 61.
} 
było ujednolicenie kształcenia kobiet ze wszystkich stanów w duchu lojalności wobec Rosji. Cele polityczne były zatem nader wyraźne ${ }^{52}$.

W styczniu 1865 r. otwarto w Warszawie rosyjskie gimnazjum wraz z przyłączonym do niego rosyjskim żeńskim progimnazjum i szkolą początkową. Na początku $1866 \mathrm{r}$. zaczęto otwierać kolejne szkoły ${ }^{53}$. Ten kierunek utrzymał się w kolejnych latach, zwłaszcza gdy ministrem oświaty został hrabia Dimitrij Tołstoj. Przez kolejnych 14 lat reformował i rozbudowywał szkolnictwo, w tym szkoły żeńskie. Ustawa z 1870 r. dzieliła dotychczasowe szkoły żeńskie na 3-letnie progimnazja i 7-letnie gimnazja. Przy tych ostatnich mogły powstawać klasy VIII o kierunku pedagogicznym. Tak zreformowane gimnazja lepiej przygotowywały do pracy pedagogicznej i studiów wyższych. Reformatorska działalność ministra Totstoja [...] - jak pisze Józef Miąso - zmierzała do modernizacji Rosji za pomoca szkoty, opartej z pozoru na wzorcach zachodnioeuropejskich, ale mającej stużyć umacnianiu carskiego samowładztwa ${ }^{54}$.

W Królestwie dominowały prywatne szkoły żeńskie, jednak ukończenie ich nie dawało wstępu na uniwersytety cesarskie. Były to szkoły 6- lub 7-klasowe, a dopiero od uchwały Dumy w 1912 r. możliwe stało się zakładanie szkół 8-klasowych ${ }^{55}$.

Inaczej zatem niż w Galicji władze rosyjskie inicjowały i zakładały średnie rządowe szkoły żeńskie - cel, który przyświecał był jednak jasny - nie chodziło o to, by stanowiły one odpowiedź na rosnące aspiracje edukacyjne i potrzeby kobiet, ale by przede wszystkim pełniły funkcje polityczne. Stąd też zapewne - w porównaniu ze szkołami prywatnymi - mała ich popularność.

Dopiero czasy II Rzeczypospolitej przyniosły zmianę sytuacji w odniesieniu do edukacji dziewcząt. Dekret „O obowiązku szkolnym” zatwierdzony przez Naczelnika Państwa Józefa Piłsudskiego w dniu 7 II 1919 r. wprowadzał obowiązek szkolny dla wszystkich dzieci w wieku od 7 do 14 lat wpierw na terenie byłego zaboru rosyjskiego, a potem na pozostałych ziemiach, przyczyniając się do ujednolicenia organizacji szkolnictwa powszechnego w całym państwie. Ten stan rzeczy potwierdzał art. 118 Konstytucji marcowej oraz ustawa „O ustroju szkolnictwa” z 11 marca 1932 r. Artykuł 15 tej ustawy stwierdzał ponadto, że młodzież, która wypetni obowiązek szkolny, a nie uczęszcza do żadnej szkoty, podlega do 18 roku życia włącznie obowiązkowemu dokształcaniu ${ }^{56}$.

Gruntowne przeobrażenia zaszły w zakresie kształcenia dziewcząt na poziomie średnim. Podstawą przebudowy szkolnictwa był opublikowany w 1919 r. Program naukowy szkoły średniej. Zapowiadano w nim utworzenie jednolitej ogólnokształcącej 8-klasowej

52 A. Winiarz, Kształcenie i wychowanie..., s. 18-19; K. Poznański, Reforma szkolna ..., s. 283-285, 309.

${ }^{53}$ K. Poznański, Reforma szkolna..., s. 304-306.

${ }^{54}$ J. Miąso, op. cit.., s. 133, 135.

55 S. Walasek, op. cit., s. 19;

${ }^{56}$ S. Mauersberg, Wykonywanie obowiazku szkolnego w niepodległej Polsce (1918-1939) „Rozprawy z dziejów oświaty" 1996, s. 157, 166-167; idem, Reformy szkolne w Drugiej Rzeczypospolitej (1918-1939), „Kwartalnik Pedagogiczny” 1995, nr 3, s. 23; S. Możdżeń, Teksty źródłowe do dziejów wychowania, t. VIII: Szkolnictwo w Polsce 1918-1945, Kielce 1994, s. 8, 17, 21. 
szkoły średniej o programach nauczania jednakowych w szkołach męskich i żeńskich. Mogły też powstawać gimnazja koedukacyjne ${ }^{57}$.

W praktyce jednak sytuacja dziewcząt w szkołach średnich była trudniejsza niż chłopców. W roku szkolnym 1937/8 istniało bowiem średnich szkół państwowych: męskich - 135, koedukacyjnych - 123, a żeńskich tylko 49. Władze chętniej bowiem otwierały i utrzymywały gimnazja męskie aniżeli żeńskie. Oznaczało to, że w dalszym ciągu dziewczętom trudniej było uzyskać wykształcenie średnie, a na pewno w wielu przypadkach było ono kosztowniejsze, ponieważ dziewczęta w większości zmuszone były uczęszczać do szkół prywatnych ${ }^{58}$.

W okresie II Rzeczypospolitej zniknęły dwa oddzielne tory kształcenia dla dziewcząt i dla chłopców, średnia szkoła żeńska zyskała oficjalne równouprawnienie, jednak w praktyce w dalszym ciągu zdobycie średniego, a w konsekwencji i wyższego wykształcenia było dla dziewcząt trudniejsze niż dla chłopców.

\section{Bibliografia}

Bartnicka K., Pensja żeńska jako substytut wychowania domowego, w: Nauczanie domowe dzieci polskich od XVIII do XX wieku, red. K. Jakubiak i A. Winiarz, Warszawa 2004.

Czajecka B., „Z domu w szeroki świat”: droga kobiet do niezależności w zaborze austriackim w latach 1890-1914, Kraków 1990.

Czajecka B., Szkoły klasztorne w Galicji w latach 1867-1914, „Nasza przeszłość” 1984, t. 61.

Dąbrowska J., Początki szkolnictwa żeńskiego - Instytut Guwernantek, w: Z dziejów polskiej kultury $i$ oświaty od średniowiecza do poczatku XX wieku, red. K. Jakubiak i T. Maliszewski, Kraków 2012.

Dutkowa R., Polityka szkolna w Galicji między autonomia a centralizmem (1861-1875), Kraków 1995.

Dutkowa R., Żeńskie gimnazja Krakowa w procesie emancypacji kobiet (1896-1918), Kraków 1995.

Dziennik ustaw i rozporzadzeń krajowych dla Królestwa Galicji i Lodomerii wraz z Wielkim Księstwem Krakowskim. Rocznik 1895, Lwów, cz. XII.

Dziennik ustaw i rozporzadzeń krajowych dla Królestwa Galicji i Lodomerii wraz z Wielkim Księstwem Krakowskim, rok 1873, cz. XXVIII.

Ender J., Sprawa kształcenia kobiet w dobie Komisji Edukacyjnej, „Przegląd Historyczno-Oświatowy" 1972, nr 3.

Hulewicz J., Sprawa wyższego wykształcenia kobiet w Polsce w wieku XIX, Kraków 1939.

Kot S., Historia wychowania, t. II, Warszawa 1996.

Lewicki J., Komisja Edukacji Narodowej w świetle ustawodawstwa szkolnego. Szkic historyczny, Warszawa 1923.

Mauersberg S., Reformy szkolne w Drugiej Rzeczypospolitej (1918-1939), „Kwartalnik Pedagogiczny" 1995, nr 3.

57 J. Sadowska, Ku szkole na miarę Drugiej Rzeczypospolitej: geneza, założenia i realizacja reformy Jędrzejewiczowskiej, Białystok 2001, s. 130.

58 A. Samsel, Koedukacja w szkole średniej w Polsce i na świecie w latach 1918-1939, świadomy wybór czy zło konieczne, „Przegląd Historyczno-Oświatowy” 2004, nr 3-4, s. 84-85. 
Mauersberg S., Wykonywanie obowiazku szkolnego w niepodległej Polsce (1918-1939) „Rozprawy z dziejów oświaty" 1996.

Miąso J., Reformy oświatowe w Prusach, Austrii i Rosji i ich wplyw na szkolnictwo na ziemiach polskich w drugiej połowie XIX wieku, „Kwartalnik Pedagogiczny” 1995, nr 3.

Miterzanka M., Działalność pedagogiczna Adama księcia Czartoryskiego generała ziem podolskich, Prace monograficzne z dziejów wychowania i szkolnictwa w Polsce, s. I, nr 8, Warszawa 1931.

Możdżeń S., Teksty źródłowe do dziejów wychowania, t. VIII: Szkolnictwo w Polsce 1918-1945, Kielce 1994.

Piramowicz G., Powinności nauczyciela, oprac. T. Mizia, Warszawa 1988.

Plany nauki dla szkół ludowych pospolitych wraz z instrukcją, Lwów 1893.

Plany naukowe dla szkót ludowych pospolitych pięcio- i sześcioklasowych męskich, żeńskich i mieszanych wraz z instrukcja, Lwów 1911.

Pohoska H., Sprawa oświaty ludu w dobie Komisji Edukacji Narodowej, Kraków 1925.

Poznański K., Osiagnięcia polskich reform szkolnych w XIX wieku, „Kwartalnik Pedagogiczny” 1995, nr 3.

Poznański K., Oświata i szkolnictwo w Królestwie Polskim 1831-1869. Lata zmagań i nadziei, t. 1: Przebudowa systemu szkolnictwa i wychowania w Królestwie Polskim w latach 1831-1839, Warszawa 2001.

Poznański K., Reforma szkolna w Królestwie Polskim w 1862 roku, Wrocław 1968.

Przepisy od Komisji Edukacji narodowej pensjo mistrzom i pensjo mistrzyniom dane, w: Ustawodawstwo szkolne za czasów Komisji Edukacji Narodowej. Rozporządzenia, ustawy pedagogiczne i organizacyjne (1773-1793), zebrał J. Lewicki, Biblioteka Polskich Pisarzy Pedagogicznych nr 2, Kraków 1925.

Sadowska J., Ku szkole na miarę Drugiej Rzeczypospolitej: geneza, zatożenia i realizacja reformy Jędrzejewiczowskiej, Białystok 2001.

Samsel A., Koedukacja w szkole średniej w Polsce i na świecie w latach 1918-1939, świadomy wybór czy zło konieczne, „Przegląd Historyczno-Oświatowy” 2004, nr 3-4.

Stinia M., Rola społeczeństwa galicyjskiego jako organizatora średniego szkolnictwa prywatnego w okresie autonomii, w: $Z$ dziejów polskiej kultury i oświaty od średniowiecza do początku XX wieku, red. K. Jakubiak i T. Maliszewski, Kraków 2012.

Suchan E., Historyczny zarys organizacji szkolnictwa elementarnego w Polsce od Komisji Edukacji Narodowej po dobę obecna, Brześć nad Bugiem 1938.

Ustawy i rozporządzenia w zakresie szkół ludowych, zebrał i ułożył K. Pierożyński, Lwów 1904.

Ustawy Komisji Edukacji Narodowej dla Stanu Akademickiego i na szkoły w krajach Rzeczypospolitej przepisane w Warszawie roku 1783, Lwów 1917.

Walasek S., Szkolnictwo średnie ogólnokształcace na ziemiach polskich w latach 1914-1923, „Acta Universitatis Wratislaviensis no 184, Prace Pedagogiczne CXII”, Wrocław 1996.

Winiarz A., Kształcenie $i$ wychowanie dziewcząt w Księstwie Warszawskim i Królestwie Polskim (1807-1905), w: Kobieta i edukacja na ziemiach polskich $w$ XIX i XX w, red. A. Żarnowska i A. Szwarc, t. II, cz. 2, Warszawa 1992.

Winiarz A., Szkolnictwo Księstwa Warszawskiego i Królestwa Polskiego (1807-1831), Lublin 2002. 
